\title{
Globalization, Endogenous Oil Price Shocks and Chinese Economic Activity
}

\section{Gulzar Khan*, Adiqa Kiani** and Ather Maqsood Ahmed ${ }^{* * *}$}

\begin{abstract}
Using a structural vector autoregressive model, this study investigates the extent to which international oil price shocks have influenced the Chinese economy over the period 1991-2014. Given China's intensified macroeconomic activity and its increasing demand for energy resources, we also examine the endogenous response of international oil prices to economic conditions in the country. To that end, we derive and empirically estimate a small open-economy New Keynesian model for China and the rest of the world. Our results show that the Chinese economy is relatively more sensitive to global economic conditions than to domestic policy actions. Global productivity shocks appear to be the most important variable causing Chinese macroeconomic activity through trade, where oil prices impact aggregate demand negatively.
\end{abstract}

Keywords: Globalization, macroeconomic fluctuations, oil price shocks, SVAR, China.

JEL classification: C32, E32, F41, Q43.

\section{Introduction}

Identifying the underlying causes and effects of an oil price shock is key to understanding its transmission mechanism and potential aftermath for oil-importing economies. It can also help in formulating an appropriate policy to counter the resulting economic instability.

It is widely held that recent global oil market developments have resulted from faster economic growth in developing economies such as China, India and Turkey. China is the world's most populous country, with a population of 1.3 billion. As the second largest economy, it has grown on

\footnotetext{
* PhD scholar, School of Economic Sciences, Federal Urdu University of Arts, Science and Technology, Islamabad.

** Associate Professor, School of Economic Sciences, Federal Urdu University of Arts, Science and Technology, Islamabad.

*** Professor, Department of Economics, School of Social Sciences and Humanities, National University of Sciences and Technology, Islamabad.
} 
average by 10 percent per annum in the last two decades and more than 500 million people have been lifted out of poverty. China is also among the world's most open trading economies. Its energy demand has risen proportionally to cater to the needs of its growing manufacturing sector: since 1993, China has shifted from being an oil exporter to an oil importer. In 2013, it became the world largest energy consumer and the second largest importer of oil after the US.

Given these features, China is often cited as one of the world's most important economic players. Arguably, its considerable demand for oil may cause high energy prices and consequently have an adverse impact on oilimporting economies through various channels. That said, China's economic growth helps promote growth in other economies through its high demand for imports and cheaper exports. Similarly, with the global economic boom, the demand for Chinese manufacturing goods has increased, in turn promoting growth in China. Thus, the interconnectedness of the Chinese economy and the rest of the world seem to be two sides of the same coin.

This study's objective is to investigate the comparative effects of global demand shocks on the Chinese economy, along with the resulting oil price shocks. It also examines oil price dynamics and the relative strength of different sources. Section 2 provides a comprehensive survey of the literature. Section 3 outlines the macroeconomic performance of the Chinese economy. Our theoretical model, derived from a New Keynesian framework, is presented in Section 4 and the estimation and identification procedure is explained in Section 5. Finally, the study's empirical evidence and concluding remarks are given in Sections 6 and 7.

\section{Literature Survey}

Since 1973, numerous studies have examined the nexus between oil price shocks and macroeconomic performance in developed economies. Hamilton's (1983) pioneering study establishes a robust causal negative relationship between international oil price movements and the US GNP for the period 1948-72. After the oil market collapsed in the 1980s and oil prices fell significantly, many observers expected an economic revival - or at least recovery - to follow. That this did not happen prompted many economists to re-examine the oil price-macroeconomy relationship.

Using extended data for the period during which oil prices fell, Mork (1989) reconsiders Hamilton's (1983) study and finds that the oil pricemacroeconomy relationship is asymmetric when oil prices increase but not 
when they decrease. Bernanke, Gertler and Watson (1997) study the role of endogenous monetary policy responses to oil price shocks and observe that the recession of the 1970s could have been avoided had the policy response been more accommodating. Studies such as Ferderer (1996) and Hooker (1996) gauge the role of uncertainty and the prevailing environment in the impact of oil price shocks.

Several recent empirical studies have discovered, however, that the oil price-macroeconomy relationship has weakened since the 1980s (see Hooker, 1999). The observed increased resilience of the global economy to oil price shocks remains a puzzle: among the different explanations for this are more flexible markets, more credible monetary policy and the smaller share of oil in production (Blanchard \& Galí, 2009; Blanchard \& Riggi, 2011). However, this argument is not plausible because it disregards the endogenous response of oil prices to global economic activity (see Woodford, 2007; Hamilton, 2009; Kilian, 2009).

As Kilian (2009) argues, oil price shocks stem from different sources and these have different implications for output and inflation, making it important to identify the causal source of the oil price shock. He classifies oil price shocks as being supply-driven (stemming from geopolitical events), demand-driven (due to improved global productivity), related to the precautionary demand for oil (resulting from geopolitical uncertainties) and related to specific oil market shocks. In the demand-driven case, given a stagnant oil supply, the increased demand for oil will push up its nominal price. Consequently, oil-importing countries will be burdened as they will have to pay more for the same quantity of oil. On the other hand, they will enjoy cheaper imports (other than oil) from more productive countries. Demand for their exports will also rise due to the productivity shock to the rest of the world.

In China's case, only limited efforts have been made to examine the oil price-macroeconomy relationship. Huang and Guo (2007) study the behavior of the Chinese real effective exchange rate (REER) in response to oil price shocks. They find that positive oil price shocks lead to a smaller currency appreciation in China relative to its trading partners, which they attribute to its smaller share of oil in production. Cong et al. (2008) demonstrate that most of China's stock market indices do not respond significantly to oil price fluctuations.

Faria et al. (2009) focus on China's export performance and find significant positive associations between oil prices and exports. Ou, Zhang 
and Wang (2012) show that the West Texas Intermediate crude oil price has had a significant effect on various domestic price indicators such as the consumer price index (CPI) and producer price index for China, although this relationship appears to have weakened up to 2011. Similarly, Wang and Zhang (2014) examine the asymmetric response of industrial production to oil price shocks and find that a fall in the oil price has a stronger positive impact on industrial production than decreases in industrial production due to an oil price increase.

At the aggregate level, Du, He and Wei (2010) and Tang, Wu and Zhang (2010) find that oil price shocks significantly affect China's macroeconomic performance. Looking at the role of expected and unexpected oil price volatility, Zhang and Chen (2014) show that oil price volatility has a bearing on the country's aggregate commodity market. In contrast, Chen, Chen and Wu's (2009) empirical study of the impact of China's economic growth on international oil prices rejects the argument that China is the main culprit behind the current oil price hike. Finally, $\mathrm{Wu}$ and Zhang (2014) revisit the role of Chinese crude oil imports in world oil price volatility for the period 2005-13. Their results do not support the hypothesis that China's crude oil imports cause Brent crude oil prices in the short run as well as long run.

Given the context described above, this study contributes to the literature by deriving and estimating an open-economy dynamic stochastic general equilibrium model for the Chinese economy.

\section{The Chinese Economy: Some Stylized Facts}

Prior to economic reforms introduced in 1979, the Chinese economy was centrally planned, poor and relatively isolated from the global economy. Post-reforms, it became one of the world's foremost emerging economies, registering an annual growth rate of almost 10 percent in the last two decades. More recently, China has emerged as the world's fastest growing economy and is currently the second largest economy after the US. Since 2000, China has been a popular destination for foreign direct investment (FDI). Annual FDI inflows to China stood at US\$121 billion in 2013 and the total stock of FDI was an estimated US\$832.9 billion through 2012 (United Nations Conference on Trade and Development, 2014). This inflow of financial resources has been accompanied by modern technology and information, enhancing China's productivity and driving its rapid economic growth. Moreover, the country's supply of cheap labor enables it to produce in bulk, making it the world's largest manufacturer. 
China's trade sector has been its second most important source of growth since the early 1990s. In 2012, it became the world's largest trading economy, overtaking the US. Over the last two decades, Chinese exports have grown by 18.5 percent and imports by 17.3 percent, creating a large trade surplus. Between 2004 and 2013, the trade surplus rose sharply from US\$32 billion to US\$261 billion. In 2013, Chinese exports constituted 12.1 percent of the world's merchandised exports, compared to 2.1 percent in 1991. China's economic growth has also relied heavily on coal and oil: in 2009 , it was the world's largest energy consumer, followed by the US. Coal accounts for the bulk of China's energy mix, constituting about 69 percent, followed by oil at 18 percent, although China is still the world's second largest oil consumer after the US. The country has significant oil reserves and was a net oil exporter until 1992. Since 1993, it has been a net oil importer, importing 5.8 million barrels per day in 2013.

These characteristics of the Chinese economy show why it is important to study the potential impact of China's growing energy demand on global energy prices. We also look at the impact of rising energy prices on global demand and inflation and the impact of global macroeconomic dynamics on China as a secondary effect.

\section{Theoretical Model}

Our theoretical model of the Chinese economy is an extension of Galí and Monacelli's (2005) model of a small, open economy within a New Keynesian framework. The rationale for adopting this model is China's imperfect market structure (centrally planned), which a New Keynesian framework can accommodate. The model is extended in several directions, with oil as a factor of production and imperfect financial markets that generate a risk premium. The macroeconomic variables of the rest of the world are assumed to be endogenous, along with oil prices. Other assumptions regarding preferences, the structure of the goods market and the state of technology remain constant.

\subsection{Household}

The domestic economy consists of $n$ consumers, each of whom seek to maximize their lifetime utility:

$$
E_{0} \sum_{t=0}^{\infty} \beta^{t}\left(\frac{C_{t}^{1-\sigma}}{1-\sigma}-\frac{N_{t}^{1+\varphi}}{1+\varphi}\right)
$$


where $N_{t}$ denotes the work effort in hours and $C_{t}$ is a composite consumption index comprising domestically produced goods $C_{H, t}=$ $\left[\int_{0}^{1} C_{H, t}(j)^{(\varsigma-1) / \varsigma} d j\right]^{\frac{\varsigma}{\varsigma-1}}$ and goods imported from the rest of the world $C_{F, t}=$ $\left[\int_{0}^{1} C_{k, t}{ }^{(\tau-1) / \tau} d i\right]^{\frac{\tau}{\tau-1}}$. $\varsigma$ is the elasticity of substitution between goods produced domestically in any country and $\tau$ is the elasticity of substitution between domestic and imported goods. $C_{k, t}$ is the index of goods imported from the $k$ th country, $\sigma$ is the degree of relative risk aversion, $\beta$ is the discount factor and $\varphi$ is the inverse elasticity of labor supply. The aggregate consumption index can be expressed as

$$
C_{t}=\left[(1-\alpha)^{\frac{1}{\tau}} C_{H, t}^{(\tau-1) / \tau}+\alpha^{\frac{1}{\tau}} C_{F, t}^{(\tau-1) / \tau}\right]^{\tau-1 / \tau}
$$

where $\alpha$ is the share of imported goods in the domestic consumer's basket and can be considered the degree of openness of the trading economy. The domestic CPI $\left(P_{t}\right)$ is the weighted sum of the domestic price index $P_{H, t}=$ $\left[\int_{0}^{1} P_{H, t}(j)^{1-\varsigma} d j\right]^{\frac{1}{1-\varsigma}}$ and imported price index $P_{F, t}=\left[\int_{0}^{1} P_{i, t}{ }^{1-\tau} d i\right]^{\frac{1}{1-\tau}}$ where $P_{i, t}=\left[\int_{0}^{1} P_{i, t}(j)^{1-\varsigma} d j\right]^{\frac{1}{1-\varsigma}}$. The domestic CPI can be written as

$$
P_{t}=\left[(1-\alpha) P_{H, t}^{1-\tau}+\alpha P_{F, t}^{1-\tau}\right]^{1 /(1-\tau)}
$$

The domestic consumer's utility maximization is subject to a lifetime budget constraint given by ${ }^{1}$

$$
P_{t} C_{t}+E_{t}\left\{T_{t, t+1} D_{t+1}\right\} \leq D_{t}+W_{t} N_{t}+T_{t}
$$

where $T_{t, t+1}$ is the stochastic discount factor and $D_{t}$ is the nominal payoff received by the household in period $t$ for the portfolio held in period $t-1$. $W_{t}$ is the nominal wage rate and $T_{t}$ denotes nominal transfer payments.

The optimization process yields the following optimality conditions:

$$
\begin{aligned}
& w_{t}-p_{t}=\sigma c_{t}+\varphi n_{t} \\
& c_{t}=-\frac{1}{\sigma}\left(i_{t}-E_{t}\left\{\pi_{t+1}\right\}-\rho\right)+E_{t}\left\{c_{t+1}\right\}
\end{aligned}
$$

\footnotetext{
${ }^{1}$ For a detailed derivation, see Galí and Monacelli (2005).
} 
where equation (5) is the household's labor supply decision and equation (6) represents the intertemporal substitution behavior in consumption. The lowercase letters are the logs of the respective variables and $E_{t}\left\{\pi_{t+1}\right\}$ is the expected price inflation in period $t+1$. Finally, $i$ is the nominal rate of interest and $\rho=-\log \beta$.

\subsection{Financial Markets}

Financial markets are integrated with the rest of the world. The bilateral real exchange rate is the ratio of the domestic country's CPI to the rest of the world's CPI expressed in the domestic country's currency $Q_{t}=$ $\frac{E_{k, t} P_{t}^{k}}{P_{t}}$.

Further, we assume that the law of one price holds for each good across small open economies. Thus, the relationship between the domestic country's CPI, domestic inflation and the REER around the symmetric steady state can be expressed as

$$
\begin{aligned}
& p_{t}=p_{H, t}+\frac{\alpha}{1-\alpha} q_{t} \\
& \pi_{t}=\pi_{H, t}+\frac{\alpha}{1-\alpha} \Delta q_{t+1}
\end{aligned}
$$

Since asset markets are assumed to be complete, with identical household preferences across the world, this implies there is a symmetric optimization problem. The rest of the world is assumed to be large enough for the small open economy to have no influence over it. Combining the Euler equations for both economies, we obtain the risk-sharing condition, which links domestic consumption to the rest of the world's consumption instead of domestic income:

$$
c_{t}=c_{t}^{*}+\frac{1}{\sigma} q_{t}
$$

Another important implication of complete asset markets is the uncovered interest parity (UIP) condition, which implies that exchange rate movements depend solely on the real interest rate differential:

$$
E_{t}\left\{\Delta q_{t+1}\right\}=\left(r_{t}-E_{t}\left\{\pi_{t+1}\right\}\right)-\left(r_{t}^{*}-E_{t}\left\{\pi_{t+1}^{*}\right\}\right)
$$

Equations (8) and (9) imply that financial market integration ensures consumption smoothing at a macro-level and that any economy can minimize idiosyncratic risk by trading with the international community. 
Since there is weak empirical evidence to suggest that the UIP condition holds in the short run (see, among others, Mark \& Wu, 1998; Hansen \& Hodrick, 1980), we incorporate a risk premium for the relationship to hold:

$$
E_{t}\left\{\Delta q_{t+1}\right\}=\left(r_{t}-E_{t}\left\{\pi_{t+1}\right\}\right)-\left(r_{t}^{*}-E_{t}\left\{\pi_{t+1}^{*}\right\}\right)+\varepsilon_{t}^{q}
$$

where $\varepsilon_{t}^{q}$ is the time-varying risk premium incorporating a transitory deviation from the UIP condition.

\subsection{Supply Side}

Firms are assumed to be identical with respect to the production process (technology). We also assume that they function in a monopolistic environment and produce differentiated products. Each firm tries to maximize its profit subject to demand conditions and its price-setting ability. It produces with constant-returns-to-scale technology, defined by a CobbDouglas production function as shown below.

$$
Y_{t}(j)=\left[A_{t} N_{t}(j)\right]^{\eta} O_{t}^{d}(j)^{1-\eta}
$$

where $O_{t}^{d}$ is the demand for oil by each firm, $A_{t}$ is labor productivity, $\eta$ is the share of labor in the production process and $1-\eta$ is the share of oil. The firm's cost minimization condition implies that its marginal products are equal:

$$
(1-\eta) W_{t} N_{t}(j)=\eta O_{t}^{d}(j) P_{O, t}
$$

where $P_{O, t}$ is the price of oil. The demand for oil by any firm is given by

$$
o_{t}^{d}=\left[\frac{\eta \sigma+1+\varphi}{1+\varphi(1-\eta)}\right] y_{t}-\left[\frac{\eta(1+\varphi)}{1+\varphi(1-\eta)}\right] a_{t}-\left[\frac{\eta}{1+\varphi(1-\eta)}\right] p_{O, t}
$$

Using the cost minimization condition, the log real marginal cost function of the domestic firm can be written as

$$
m c_{t}=\eta w_{t}+(1-\eta) p_{O, t}-\eta a_{t}-p_{H, t}
$$

Assuming prices are sticky in the goods market, the price-setting mechanism is assumed to follow Calvo's (1983) structure, where a random fraction $\Omega$ of firms cannot adjust their prices optimally. Thus, $\Omega$ is the firm's inability to adjust its prices in period $t$ and measures price rigidity. The optimal price setting, subject to the firm's demand schedule, yields a traditional Phillips curve: 


$$
\pi_{H, t}=\beta E_{t}\left\{\pi_{H, t+1}\right\}+\lambda \widehat{m c}_{t}
$$

where $\lambda=\frac{(1-\theta)(1-\beta \theta)}{\theta}$ and $\widehat{m c}_{t}$ is the deviation of the real marginal cost from its flexible price equilibrium.

\subsection{Demand-Side Equilibrium}

$$
Y_{t}(j)=C_{H, t}(j)+\int_{0}^{1} C_{H, t}^{i}(j) d i
$$

where $Y_{t}(j)$ is the total production of commodity $j, C_{H, t}(j)$ is the total final consumption expenditure of the domestic household and $\int_{0}^{1} C_{H, t}^{i}(j) d i$ denotes total exports to the rest of the world. Using the optimal allocation condition of resources for a small open economy and the rest of the world, and given the real exchange rate definition and identical preferences, the symmetric steady-state aggregate demand function can be written as

$$
y_{t}=c_{t}+\tau\left(p_{t}-p_{H, t}\right)+\alpha\left(\tau-\frac{1}{\sigma}\right) q_{t}
$$

Using equation (7a), the risk-sharing condition and Euler condition, we obtain a dynamic IS equation:

$$
y_{t}=E_{t}\left\{y_{t+1}\right\}-\frac{1}{\sigma}\left(i_{t}-E_{t}\left\{\pi_{t+1}\right\}\right)-\alpha\left[\frac{1+(2-\alpha)(\tau \sigma-1)}{\sigma(1-\alpha)}\right] E_{t}\left\{\Delta q_{t+1}\right\}
$$

\subsection{Supply-Side Equilibrium}

This section establishes the relationship between real marginal cost and economic activity and derives the New Keynesian Phillips curve. After substituting equations (5) and (7), equation (14) can be rewritten as

$$
m c_{t}=-\eta a_{t}+\eta\left(\sigma c_{t}+\varphi n_{t}\right)+(1-\eta) \tilde{p}_{O, t}+\frac{\alpha}{1-\alpha} q_{t}
$$

where $\tilde{p}_{O, t}$ is the real price of oil. Now, inserting the cost minimization condition (12), production function (11) and risk-sharing condition (8) into the above equation, we obtain

$$
m c_{t}=-\xi_{1} a_{t}+\xi_{2} y_{t}^{*}+\xi_{3} y_{t}+\xi_{4} \tilde{p}_{O, t}+\xi_{5} q_{t}
$$

where $\xi_{1}=\frac{\eta(1+\varphi)}{1+\varphi(1-\eta)^{\prime}}, \quad \xi_{2}=\frac{\eta \sigma}{1+\varphi(1-\eta)^{\prime}}, \quad \xi_{3}=\frac{\eta \varphi}{1+\varphi(1-\eta)^{\prime}}, \quad \xi_{4}=\frac{(1+\varphi)(1-\eta)}{1+\varphi(1-\eta)}, \quad \xi_{5}=$ $\frac{\eta}{1+\varphi(1-\eta)}+\frac{\alpha}{1-\alpha}$ and $\xi_{6}=\frac{\sigma}{\alpha \gamma \sigma(2-\alpha)+(1-\alpha)^{2}}$. 
Inserting equation (20) into the Phillips curve (15) and incorporating a cost-push shock, such as in Clarida, Galí and Gertler (2002), yields

$$
\pi_{t}=\beta E_{t}\left\{\pi_{t+1}\right\}+\lambda \xi_{8} x_{\mathrm{t}}+\lambda \xi_{9} q_{t}+\lambda \xi_{10} \tilde{p}_{o, t}+\varepsilon_{t}^{\pi}
$$

Using the definition of the output gap and the AR(1) productivity process, and assuming that government spending is exogenously determined, the New Keynesian IS equation derived is

$$
\begin{aligned}
& x_{t}=E_{t}\left\{x_{t+1}\right\}-\frac{1}{\sigma}\left(i_{t}-E_{t}\left\{\pi_{t+1}\right\}\right)-\alpha\left[\frac{1+(2-\alpha)(\tau \sigma-1)}{\sigma(1-\alpha)}\right] E_{t}\left\{\Delta q_{t+1}\right\}- \\
& \frac{\left(\xi_{2}-\xi_{6}\right)}{\left(\xi_{3}+\xi_{6}\right)} E_{t}\left\{\Delta y_{t+1}^{*}\right\}-\frac{\xi_{4}}{\left(\xi_{3}+\xi_{6}\right)} E_{t}\left\{\pi_{O, t+1}^{*}\right\}+\varepsilon_{t}^{a}
\end{aligned}
$$

where $\varepsilon_{t}^{a}$ is the shock to domestic productivity. We assume that monetary policy is conducted according to the forward-looking Taylor rule:

$$
i_{t}=\phi_{\pi} E_{t}\left\{\pi_{t+1}-\pi^{T}\right\}+\phi_{x} x_{t}+\varepsilon_{t}^{i}
$$

where $\pi^{T}$ is the target inflation rate and $\varepsilon_{t}^{i}$ denotes the interest rate shock. The rest of the world's economy evolves in a closed economy framework, with no influence from the small open economy. Other assumptions concerning preferences, technology and market structure remain constant, such that the structural equations describing the rest of the world are:

$$
\begin{aligned}
x_{t}^{*}= & E_{t}\left\{x_{t+1}^{*}\right\}-\Pi_{1}\left(r_{t}^{*}-E_{t}\left\{\pi_{t+1}^{*}\right\}\right)-\Pi_{2} E_{t}\left\{\pi_{O, t+1}^{*}\right\}-\Pi_{3}(1- \\
& \left.\rho_{a^{*}}\right) a_{t}^{*}+\varepsilon_{t}^{a^{*}} \\
\pi_{t}^{*}= & \beta E_{t}\left\{\pi_{t+1}^{*}\right\}+\lambda \Pi_{4} x_{t}^{*}+\lambda \Pi_{5} \tilde{p}_{O, t}^{*}+\varepsilon_{t}^{\pi *} \\
i_{t}^{*}= & \phi_{\pi}^{*} \pi_{t}^{*}+\varepsilon_{t}^{i *}
\end{aligned}
$$

\subsection{Oil Market Equilibrium}

We assume that the oil supply is exogenously determined and follows an AR(1) process, as given in Backus and Crucini (2000):

$$
o_{t}^{S *}=\rho_{O} o_{t-1}^{S *}+\varrho_{t}
$$

Firms operating in the rest of the world are assumed to influence the world oil price. Their demand for oil is given by

$$
o_{t}^{d *}=\left[\frac{\eta \sigma+1+\varphi}{1+\varphi(1-\eta)}\right] y_{t}^{*}-\left[\frac{\eta(1+\varphi)}{1+\varphi(1-\eta)}\right] a_{t}^{*}-\left[\frac{\eta}{1+\varphi(1-\eta)}\right] \tilde{p}_{O, t}^{*}
$$


Thus, the equilibrium price in the international market can be obtained through the market clearing condition:

$$
\tilde{p}_{O, t}^{*}=\Lambda_{1} y_{t}^{*}-\Lambda_{2} a_{t}^{*}-\Lambda_{3} o_{t}^{s *}+\varepsilon_{t}^{p o}
$$

where $\Lambda_{1}=\sigma+\frac{(1+\varphi)}{\eta}, \Lambda_{2}=1+\varphi$ and $\Lambda_{3}=\frac{1+\varphi(1-\eta)}{\eta}$.

\section{Methodology}

The rational expectations hypothesis assumes that rational and future-oriented economic agents give more weight to expected movements in economic variables than to observed times series. This implies that they update their information set consistently and revise their expectations. Given this, modern macroeconomists have devised micro-foundational models in which the economic agent's decisions stem from intertemporal optimization problems. The core model is estimated using Keating's (1990, 2000) two-step procedure. For a clear exposition of the methodology for estimating a system of equations using the full information maximum likelihood method, see Leu (2011) and Nawaz and Ahmed (2015).

\subsection{Identification Problem}

The system of structural equations representing the open economy and the rest of the world (Keating, 1990; Leu, 2011) derived in the previous section can be written as:

$$
\begin{aligned}
x_{t}= & \alpha_{0}+E_{t}\left\{x_{t+1}\right\}-\alpha_{1}\left(i_{t}-E_{t}\left\{\pi_{t+1}\right\}\right)-\alpha_{2} E_{t}\left\{\tilde{\pi}_{o, t+1}\right\}- \\
& \alpha_{3} E_{t}\left\{\Delta q_{t+1}\right\}-\alpha_{4} E_{t}\left\{x_{t+1}^{*}\right\}+\varepsilon_{t}^{a} \\
\pi_{t}= & \beta_{0}+\beta_{1} E_{t}\left\{\pi_{t+1}\right\}+\beta_{2} x_{t}+\beta_{3} \tilde{p}_{o, t}+\beta_{4} q_{t}+\varepsilon_{t}^{\pi} \\
q_{t}= & \gamma_{0}+E_{t}\left\{q_{t+1}\right\}-\gamma_{1}\left(i_{t}-E_{t}\left\{\pi_{t+1}\right\}\right)+\left(i_{t}^{*}-E_{t}\left\{\pi_{t+1}^{*}\right\}\right)+\varepsilon_{t}^{q} \\
i_{t}= & \phi_{0}+\phi_{\pi} E_{t}\left\{\pi_{t+1}\right\}+\phi_{x} x_{t}+\varepsilon_{t}^{i} \\
x_{t}^{*}= & \alpha_{0}^{*}+E_{t}\left\{x_{t+1}^{*}\right\}-\alpha_{1}^{*}\left(r_{t}^{*}-E_{t}\left\{\pi_{t+1}^{*}\right\}\right)-\alpha_{2}^{*} E_{t}\left\{\tilde{\pi}_{O, t+1}^{*}\right\}+\varepsilon_{t}^{f a *} \\
\pi_{t}^{*}= & \beta_{0}^{*}+\beta_{1}^{*} E_{t}\left\{\pi_{t+1}^{*}\right\}+\beta_{2}^{*} x_{t}^{*}+\beta_{3}^{*} \tilde{p}_{o, t}+\varepsilon_{t}^{\pi *} \\
i_{t}^{*}= & \phi_{0}^{*}+\phi_{\pi}^{*} \pi_{t}^{*}+\varepsilon_{t}^{i *} \\
p_{o, t}= & \rho_{o}+\rho_{1} x_{t}^{*}+\varepsilon_{t}^{o p}
\end{aligned}
$$


To incorporate short-run dynamics and the revision of expectations in a structural vector autoregressive (VAR) framework, we need to convert the system of structural equations described by (5.1) to (5.8) into structural shocks and VAR innovation representations as given below.

$$
\begin{aligned}
\varepsilon_{t}^{f a}= & e_{t}^{x}-E_{t}\left\{x_{t+1}\right\}+\alpha_{1}\left(e_{t}^{i}-\left(E_{t}\left\{\pi_{t+1}\right\}-E_{t-1}\left\{\pi_{t+1}\right\}\right)\right)+ \\
& \alpha_{2}\left\{\left(E_{t}\left\{P_{o, t+1}\right\}-E_{t-1}\left\{P_{o, t+1}\right\}\right)-e_{t}^{o p}\right\} \\
& \alpha_{3}\left(E_{t}\left\{q_{t+1}\right\}-E_{t-1}\left\{q_{t+1}\right\}\right)-e_{t}^{q}+\alpha_{4}\left(E_{t}\left\{x_{t+1}^{*}\right\}-E_{t-1}\left\{x_{t+1}^{*}\right\}\right)- \\
& e_{t}^{x *} \\
\varepsilon_{t}^{\pi}= & e_{t}^{\pi}-\beta_{1}\left(E_{t}\left\{\pi_{t+1}\right\}-E_{t-1}\left\{\pi_{t+1}\right\}\right)-\beta_{2} e_{t}^{x}-\beta_{3} e_{t}^{o p}-\beta_{4} e_{t}^{q} \\
\varepsilon_{t}^{q}= & e_{t}^{q}-\left(E_{t}\left\{q_{t+1}\right\}-E_{t-1}\left\{q_{t+1}\right\}\right)+\gamma_{1}\left(e_{t}^{i}-\left(E_{t}\left\{\pi_{t+1}\right\}-\right.\right. \\
& \left.\left.E_{t-1}\left\{\pi_{t+1}\right\}\right)\right)-\left(e_{t}^{i *}-\left(E_{t}\left\{\pi_{t+1}^{*}\right\}-E_{t-1}\left\{\pi_{t+1}^{*}\right\}\right)\right) \\
\varepsilon_{t}^{i}= & e_{t}^{i}-\phi_{\pi}\left(E_{t}\left\{\pi_{t+1}\right\}-E_{t-1}\left\{\pi_{t+1}\right\}\right)-\phi_{x} e_{t}^{x} \\
\varepsilon_{t}^{f a *}= & e_{t}^{x *}-\left(E_{t}\left\{x_{t+1}^{*}\right\}-E_{t-1}\left\{x_{t+1}^{*}\right\}\right)+\alpha_{1}^{*}\left(e_{t}^{i *}-\left(E_{t}\left\{\pi_{t+1}^{*}\right\}-\right.\right. \\
& \left.\left.\left.E_{t-1}\left\{\pi_{t+1}^{*}\right\}\right)\right)+\alpha_{2}^{*}\left(E_{t} \widetilde{\{P}_{o, t+1}\right\}-E_{t-1}\left\{P_{o, t+1}\right\}\right) \\
\varepsilon_{t}^{\pi *}= & e_{t}^{\pi *}-\beta_{1}^{*}\left(E_{t}\left\{\pi_{t+1}^{*}\right\}-E_{t-1}\left\{\pi_{t+1}^{*}\right\}\right)-\beta_{2}^{*} e_{t}^{x *}-\beta_{3}^{*} e_{t}^{o p} \\
\varepsilon_{t}^{i *}= & e_{t}^{i *}-\phi_{\pi}^{*} e_{t}^{\pi *} \\
\varepsilon_{t}^{o p}= & e_{t}^{o p}-\rho_{1} e_{t}^{x *}
\end{aligned}
$$

where $e_{t}^{y}=y_{t}-E_{t-1} y_{t}$ is the VAR innovation for each endogenous variable and $E_{t}\left\{y_{t+1}\right\}-E_{t-1}\left\{y_{t+1}\right\}$ denotes the process by which rational economic agents revise their expectations. To estimate the terms involved in updating future expectations - of the domestic output gap, the real price of oil, domestic inflation, the REER, global demand and global inflation $\left(x_{t}, \pi_{t}, q_{t}, p_{o, t}, x_{t}^{*}, \pi_{t}^{*}\right)$ - the unrestricted stacked VAR form can be written as

$$
Y_{t}=A Y_{t-1}+Q e_{t}
$$

Assuming the system follows an AR(1) process, then by the same approach,

$$
E_{t} Y_{t+1}=A Y_{t}
$$

Since we have six variables with a forward-looking component, we generate the following vector to locate each endogenous variable: 
$r_{y}^{\prime}=(1,0,0,0,0,0 \ldots 0)$ for the first endogenous variable

The location will change for the next variable to be located and so on. Thus, the expected value of any endogenous variable one period ahead can be achieved by multiplying (5.10) by the vector we constructed in (5.11), such that

$$
E_{t} Y_{t+1}=r_{y}^{\prime} A Y_{t}
$$

The expectations revision process as defined above is the difference between the observed value and its expected value in period $t-1$. Thus,

$$
\begin{aligned}
& \quad E_{t} Y_{t+1}-E_{t-1} Y_{t+1}=\dot{r}_{y}^{\prime} A Y_{t}-\dot{r}_{y}^{\prime} A E_{t-1} Y_{t} \\
& =\dot{r}_{y}^{\prime} A\left(Y_{t}-E_{t-1} Y_{t}\right)
\end{aligned}
$$

Using (5.9), we obtain

$$
=r_{y} A Q e_{t}
$$

Inserting the final solution into the system of structural equations (5.1a) to (5.8a) expressed in VAR innovations yields:

$$
\begin{aligned}
\varepsilon_{t}^{a}= & e_{t}^{x}-\left(r_{x}^{\prime} A Q e_{t}\right)+\alpha_{1}\left(e_{t}^{i}-\left(r_{\pi}^{\prime} A Q e_{t}\right)\right)+\alpha_{2}\left\{\left(r_{o p}^{\prime} A Q e_{t}\right)-e_{t}^{o p}\right\} \\
& \alpha_{3}\left(r_{q}^{\prime} A Q e_{t}\right)-e_{t}^{q}+\alpha_{4}\left(r_{x *}^{\prime} A Q e_{t}\right)-e_{t}^{x *} \\
\varepsilon_{t}^{\pi}= & e_{t}^{\pi}-\beta_{1}\left(r_{\pi}^{\prime} A Q e_{t}\right)-\beta_{2} e_{t}^{x}-\beta_{3} e_{t}^{o p}-\beta_{4} e_{t}^{q} \\
\varepsilon_{t}^{q}= & e_{t}^{q}-\left(r_{q}^{\prime} A Q e_{t}\right)+\gamma_{1}\left(e_{t}^{i}-\left(r_{\pi}^{\prime} A Q e_{t}\right)\right)-\left(e_{t}^{i *}-\left(r_{\pi *}^{\prime} A Q e_{t}\right)\right) \\
\varepsilon_{t}^{i}= & e_{t}^{i}-\phi_{\pi}\left(r_{\pi}^{\prime} A Q e_{t}\right)-\phi_{x} e_{t}^{x} \\
\varepsilon_{t}^{f a *}= & e_{t}^{x *}-\left(r_{x *}^{\prime} A Q e_{t}\right)+\alpha_{1}^{*}\left(e_{t}^{i *}-\left(r_{\pi *}^{\prime} A Q e_{t}\right)\right)+\alpha_{2}^{*}\left(r_{o p}^{\prime} A Q e_{t}\right) \\
\varepsilon_{t}^{\pi *}= & e_{t}^{\pi *}-\beta_{1}^{*}\left(r_{\pi *}^{\prime} A Q e_{t}\right)-\beta_{2}^{*} e_{t}^{x *}-\beta_{3}^{*} e_{t}^{o p} \\
\varepsilon_{t}^{i *}= & e_{t}^{i *}-\phi_{\pi}^{*} e_{t}^{\pi *} \\
\varepsilon_{t}^{o p}= & e_{t}^{o p}-\rho_{1} e_{t}^{x *}
\end{aligned}
$$




\subsection{Estimation Under Rational Expectation Restrictions}

The matrix form of the dynamic structural model of the open economy can be written as

$$
3_{0} y_{t}=3_{1} y_{t}+\cdots 3_{q} y_{t-q}+\mathcal{D}_{0} z_{t}+\cdots+\mathcal{D}_{k} z_{t-k}+\varepsilon_{t}, \varepsilon_{t} \sim(0, Z)(5.22)
$$

where $y_{t}=\left(x_{t}, \pi_{t}, q_{t}, i_{t}, x_{t}^{*}, \pi_{t}^{*}, i_{t}^{*}, p_{o, t}\right)$ is a vector of domestic and foreign endogenous variables and $z_{t}=\left(a_{t}, s_{t}, a_{t}^{*}\right)$ is a vector of exogenous variables. 3 and $\mathcal{D}$ are coefficient matrices for the endogenous and exogenous variables with different lags of order $q$ and $k$. The term $\varepsilon_{t}=$ $\left(\varepsilon_{t}^{f a}, \varepsilon_{t}^{\pi}, \varepsilon_{t}^{q}, \varepsilon_{t}^{i}, \varepsilon_{t}^{f a *}, \varepsilon_{t}^{\pi *}, \varepsilon_{t}^{i *}, \varepsilon_{t}^{o p}\right)$ includes structural shocks. The reducedform VAR is obtained by multiplying the dynamic structural model by $3_{0}^{-1}$ as follows:

$$
\begin{aligned}
y_{t}= & \mathcal{V}_{1} y_{t-1}+\cdots \mathcal{V}_{q} y_{t-q}+F_{1} z_{t-1}+\cdots+F_{k} z_{t-k}+e_{t}, \varepsilon_{t} \sim \\
& (0, Z)
\end{aligned}
$$

where $\mathcal{V}_{i}=3_{0}^{-1} 3_{i}, F_{i}=3_{0}^{-1} \mathcal{D}_{i}$ and $e_{t}=3_{0}^{-1} \varepsilon_{t}$.

\section{Empirical Results}

The estimation has two steps. We start by estimating the reducedform VAR and obtaining parameter coefficients in combination with the rational expectation restrictions imposed on $3_{0}$. The exclusion restrictions located on the contemporaneous exogenous variables are in $\mathcal{D}_{0}$. Next, assuming structural disturbances are i.i.d. and normally distributed, we estimate the system using the maximum likelihood method. A comprehensive analysis is carried out by computing the impulse response functions (IRFs) and variance decomposition.

\subsection{Data and Diagnostic Assessment}

The model is estimated using quarterly data for the period 1991Q1 to 2013Q4, with a total of 92 observations. It comprises 11 variables - eight endogenous and three exogenous. To adjust for seasonal variation, three dummies are introduced, along with a constant term. The domestic endogenous variables include the output gap, inflation rate, REER and interest rate. The endogenous variables representing the rest of the world include the output gap (world GDP), inflation rate (US), interest rate (Federal funds rate) and nominal price of oil (Dubai, Fateh). Productivity and oil supply (million barrels per day) are exogenous variables. The 
output gap is computed by applying the Hodrick-Prescott filter to time series data for China's real GDP. Productivity is computed as the log difference between GDP and the labor force. The other variables are constructed as theoretical measures, as stated in the model. The data series for the variables (except oil supply) were obtained from the International Financial Statistics database. The oil supply data was obtained from the International Energy Agency database.

We use the augmented Dickey-Fuller test to check the nonstationarity of the data at level and first-order difference without intercept. The lag order is determined using the Akaike information criterion. The result confirms the existence of a unit root at level, but the data appears to be stationary when first-order differenced. An asymmetric VAR approach is adopted to achieve greater flexibility in dynamic specifications. Different lag lengths are specified for the endogenous and exogenous variables. Prior to estimation, we use various diagnostic tests to ensure the statistical adequacy of the reduced-form VAR model (results not reported here). We find no evidence of serial correlation or heteroskedasticity and the VAR residuals are normally distributed. Overall, the residual diagnostic tests support the statistical adequacy of the reduced-form VAR structure.

\subsection{Global Demand Shock}

We test the extent to which recent global economic conditions characterized by a global economic boom and energy price hike - can explain variations in China's output growth, inflation rate, REER and interest rate. The dynamic response of the target variables is estimated through IRFs and variance decomposition. Given the scope and length of this article, the discussion is confined to the relative impact of an endogenous oil price shock in the presence of a global economic boom and the impact of an increase in global demand for goods and services.

Our results for the impact of a global demand shock are largely consistent with the literature (see Blanchard \& Galí, 2009; Kilian, 2009; Campolmi, 2008) and confirm that China's economic performance depends considerably on global economic conditions (see Figure 1). The domestic output gap responds appreciably to a global demand shock. A positive shock to global demand promptly increases the domestic output gap; the impact persists for a year, peaking in the first quarter. However, in the long run, the output gap remains below the steady-state level for the next six quarters. 
Figure 1: IRFs for a one-standard deviation shock to global output Domestic Global

Output gap
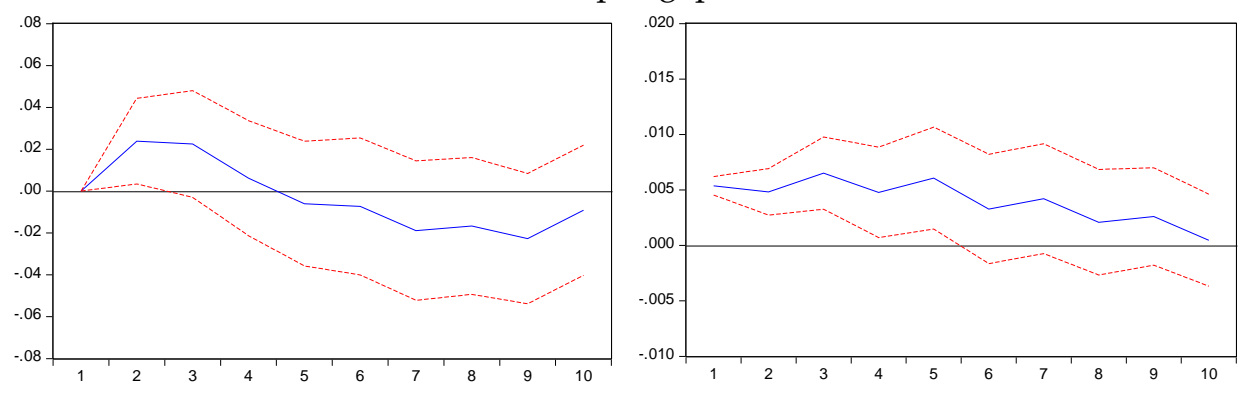

Inflation rate
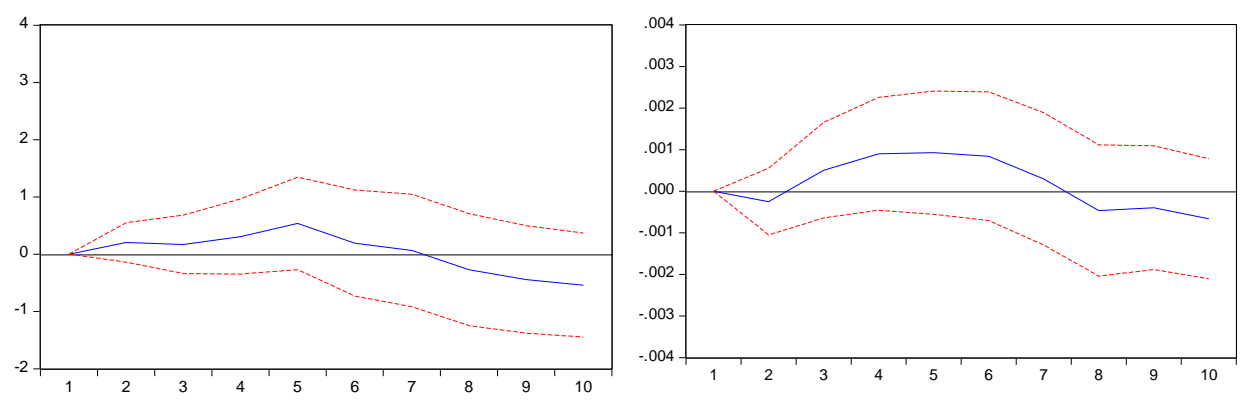

Interest rate
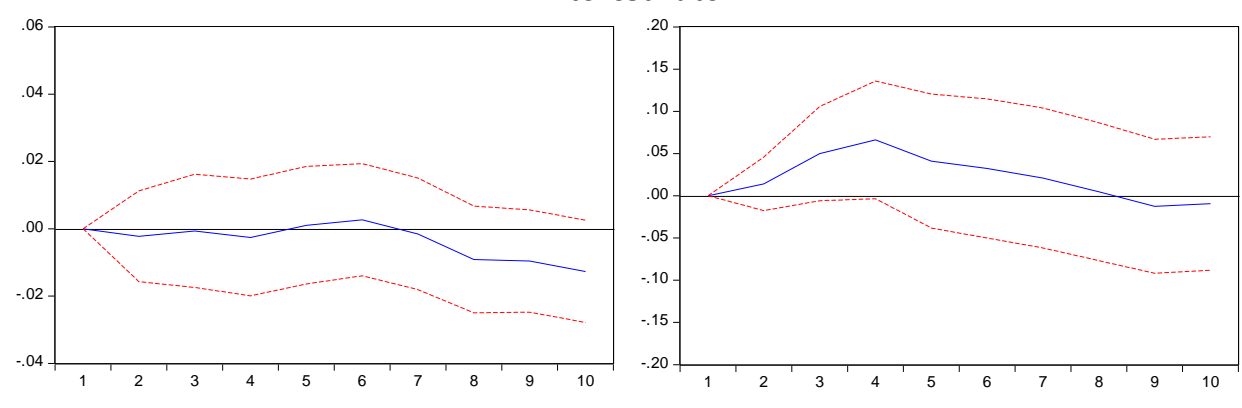

REER

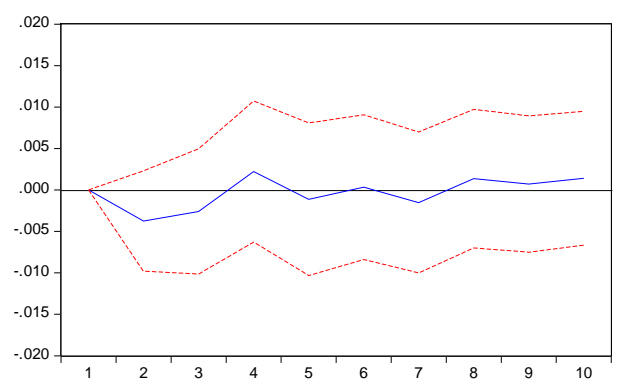

Real price of oil

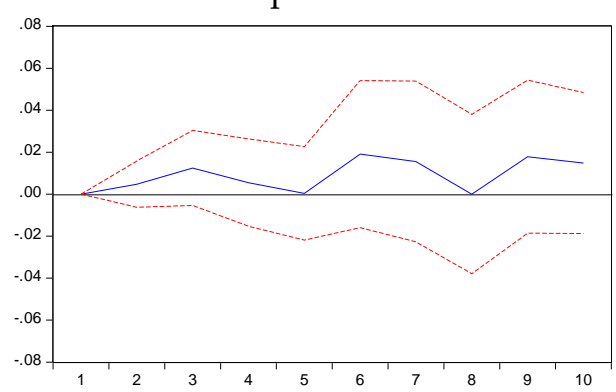


Domestic price inflation remains relatively unaffected or is slightly higher than the steady-state level in the fifth and sixth quarters. The REER depreciates significantly and takes four quarters to adjust. The monetary authority responds with an accommodative policy taking into account the general price stability. However, if we look at the rest of the world's macroeconomic dynamics, substantial price inflation is evident, which persists for about eight quarters after the global economy experienced the demand shock. The monetary authorities in the rest of the world are more concerned about economic stability (inflation) and respond aggressively with higher interest rates.

The most striking result is the positive relationship between the global demand shock and the price of oil. The real price of oil rises as the demand for other goods increases, but never dips below the steady-state value. The oil price movement is cyclical, but stays above its steady-state level. Each cycle takes four to five quarters to complete. Overall, the analysis implies that global demand shocks have a positive impact on the Chinese economy. These results are in line with Sun and Heshmati (2010) and Fan (2008) who find that the international trade volume and structure favor Chinese exports and stimulate economic growth in the country.

\subsection{Oil Price Shock}

Given the potentially positive impact of global demand on Chinese exports during the last two decades and the country's financial integration with the rest of the world, we incorporate the impact of an endogenous oil price increase on the Chinese economy (Figure 2). As discussed above, global demand shocks have had a strong impact on China's output growth, with China becoming the world's second largest economy and second largest importer of oil after the US in 2010. 
Figure 2: IRFs for a one-standard deviation shock to the price of oil

Domestic

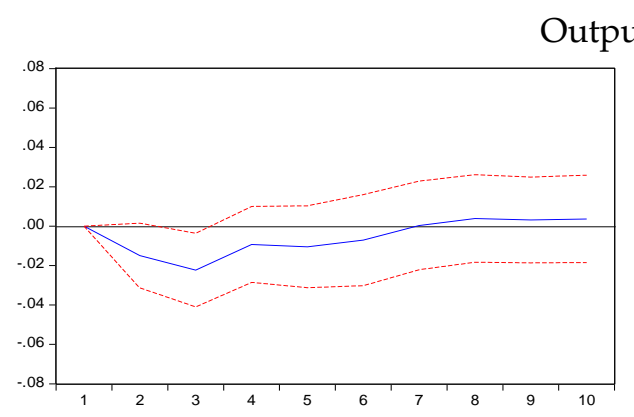

Inflation rate
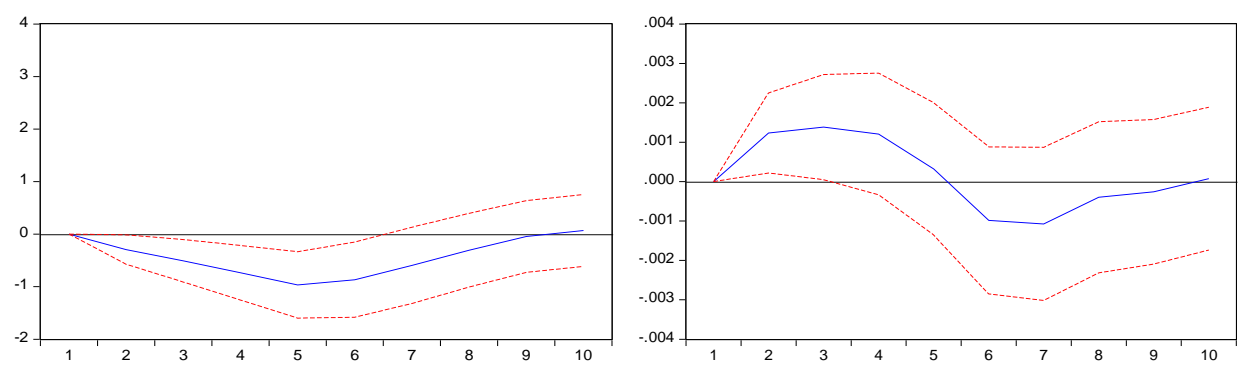

Interest rate

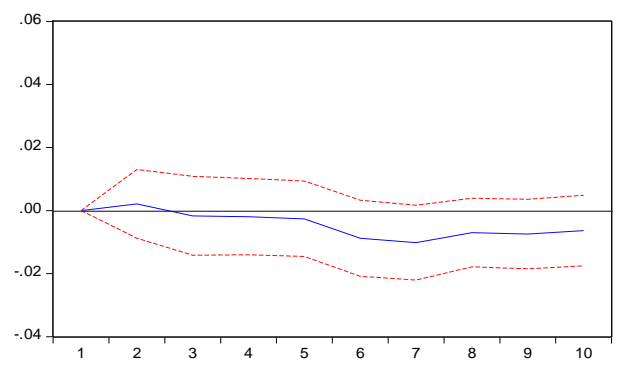

REER

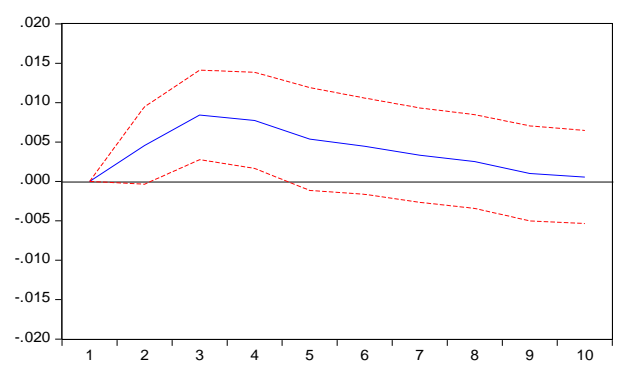

Global

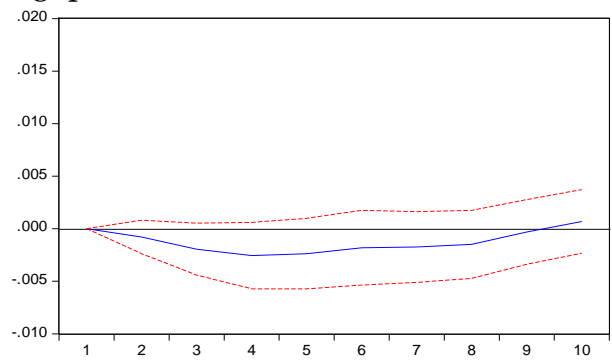

We find a substantial drop in China's output gap, which persists for about seven quarters after an oil price increase. The output gap falls promptly, reaching its lowest level in the third quarter, and then starts to 
recover in the fourth quarter. The global output gap also declines due to the positive oil price shock, which strengthens the latter's distortionary consequences. However, we find no signs of price inflation. A possible explanation for the low inflation rate lies in the economy's greater dependence on coal and other domestic energy resources. The REER depreciates significantly after an oil price hike episode and takes ten quarters to readjust. As there is no (or low) inflation, the monetary authority does not respond in the short run. However, it introduces an expansionary monetary policy, given the observed deflationary trends.

Tang et al. (2010) report comparable results for the Chinese economy. Although their analysis emphasizes the long-run consequences in a closed economy setup, they explain the output drop with a declining capacity utilization ratio in the short run as the effect of oil prices - the principal channel - hits the economy. In an open-economy framework, however, we cannot confirm the supply-side effect, even in the short run.

Unlike the supply-side channel, the demand-side channel seems to play a crucial role in domestic output. China is an export-oriented economy and its past high economic growth stems (in addition to FDI) mainly from outstanding growth in exports. However, the global demand for goods and services declines immediately following the oil price shock. Here, the decline in global demand is caused by the demand-side channel as well as supplyside channel. The demand-side channel works through a discretionary income effect, operating cost effect, uncertainty effect and an increase in precautionary saving. The supply-side channel affects firm production via higher marginal costs (Edelstein \& Kilian, 2007, 2009). The lower global demand and supply spiral puts downward pressure on the demand for Chinese exports. FDI also declines as firms in the rest of the world operate below capacity and make less or no profit in addition to low private savings.

\subsection{Variance Decomposition Analysis}

The forecast error variance decomposition (FEVD) analysis demonstrates that external global factors, including world inflation, world demand and oil price shocks (which represent global economic activity), have a strong impact on China's economic activity. The world demand shock is the leading source of variation, accounting for 55 percent of the variation in domestic output in the short run, followed by the global costpush shock, which explains about 37 percent of the fluctuations in domestic output. The endogenous oil price shock is the third source of the domestic output gap: it explains 6 percent of the demand forecast variance error, 
which declines slowly over five years. Domestic shocks generated by fiscal policy, the cost push, risk premium and interest rate have a negligible impact on China's domestic output gap (Table 1).

Table 1: FEVD analysis for output gap

\begin{tabular}{lccccccccc}
\hline Period & SE & $\begin{array}{c}\text { Fiscal } \\
\text { policy } \\
\text { shock }\end{array}$ & $\begin{array}{c}\text { Cost } \\
\text { push } \\
\text { shock }\end{array}$ & $\begin{array}{c}\text { Risk } \\
\text { premium } \\
\text { shock }\end{array}$ & $\begin{array}{c}\text { Interest } \\
\text { rate } \\
\text { shock }\end{array}$ & $\begin{array}{c}\text { Global } \\
\text { demand } \\
\text { shock }\end{array}$ & $\begin{array}{c}\text { Global } \\
\text { cost } \\
\text { push } \\
\text { shock }\end{array}$ & $\begin{array}{c}\text { Global } \\
\text { interest } \\
\text { rate } \\
\text { shock }\end{array}$ & $\begin{array}{c}\text { Oil } \\
\text { price } \\
\text { shock }\end{array}$ \\
\hline 1 & 22.80585 & 0.143617 & 0.008240 & 0.060592 & 0.031687 & 55.40576 & 37.59282 & 0.455745 & 6.301538 \\
2 & 25.51746 & 0.144563 & 0.007702 & 0.055633 & 0.067025 & 56.83081 & 37.31439 & 0.364967 & 5.214913 \\
3 & 27.91307 & 0.172733 & 0.007233 & 0.048466 & 0.137789 & 57.57746 & 37.02728 & 0.305252 & 4.723793 \\
4 & 33.85119 & 0.127795 & 0.007204 & 0.035871 & 0.148288 & 56.75001 & 37.79668 & 0.300382 & 4.833780 \\
8 & 40.59025 & 0.142892 & 0.007361 & 0.054769 & 0.131788 & 57.94582 & 37.11797 & 0.289850 & 4.309558 \\
12 & 52.86315 & 0.150100 & 0.007579 & 0.067994 & 0.110581 & 58.22773 & 36.50305 & 0.270286 & 4.662679 \\
16 & 53.46388 & 0.148110 & 0.007493 & 0.068538 & 0.109330 & 58.34027 & 36.46577 & 0.265667 & 4.594820 \\
20 & 53.86733 & 0.152262 & 0.007481 & 0.068901 & 0.117362 & 58.30811 & 36.50614 & 0.268983 & 4.570759 \\
\hline
\end{tabular}

The inflation rate dynamics are different (Table 2). In the first quarter, the oil price shock explains about 36.47 percent of the variation in domestic inflation, but this declines steadily in the second quarter and is the least important source of domestic inflation fluctuations in the long run. The global demand shock is found to be the most important source of inflation rate variability. It accounts for 41 percent of the variation in domestic inflation in the first quarter, rising steadily and explaining about 61 percent of the inflation forecast variance error. The shock to global inflation is the second most important source of variation. In the first quarter, it explains 17 percent of the variation; this increases in the long run, capturing 36 percent of the variation.

Table 2: FEVD analysis for inflation rate

\begin{tabular}{lccccccccc}
\hline Period & SE & $\begin{array}{c}\text { Fiscal } \\
\text { policy } \\
\text { shock }\end{array}$ & $\begin{array}{c}\text { Cost } \\
\text { push } \\
\text { shock }\end{array}$ & $\begin{array}{c}\text { Risk } \\
\text { premium } \\
\text { shock }\end{array}$ & $\begin{array}{c}\text { Interest } \\
\text { rate } \\
\text { shock }\end{array}$ & $\begin{array}{c}\text { Global } \\
\text { demand } \\
\text { shock }\end{array}$ & $\begin{array}{c}\text { Global } \\
\text { cost } \\
\text { push } \\
\text { shock }\end{array}$ & $\begin{array}{c}\text { Global } \\
\text { interest } \\
\text { rate } \\
\text { shock }\end{array}$ & $\begin{array}{c}\text { Oil } \\
\text { Price } \\
\text { shock }\end{array}$ \\
\hline 1 & 5.899661 & 1.191599 & 3.149161 & 0.075396 & 0.079679 & 41.73740 & 17.16211 & 0.137822 & 36.46684 \\
2 & 10.44080 & 9.571692 & 1.010259 & 0.283663 & 4.542782 & 30.48568 & 35.68626 & 0.885170 & 17.53450 \\
3 & 311.6898 & 0.010740 & 0.006587 & 0.062212 & 0.015611 & 60.04360 & 36.33626 & 0.131760 & 3.393224 \\
4 & 590.4548 & 0.003467 & 0.005217 & 0.053404 & 0.019212 & 59.64439 & 36.65766 & 0.131801 & 3.484851 \\
8 & 881.5349 & 0.011018 & 0.003556 & 0.054390 & 0.019284 & 59.06980 & 36.61908 & 0.189969 & 4.032903 \\
12 & 1420.756 & 0.027700 & 0.004165 & 0.076714 & 0.013843 & 61.29224 & 36.01531 & 0.138051 & 2.431981 \\
16 & 1685.301 & 0.023465 & 0.004617 & 0.072318 & 0.014077 & 61.44541 & 35.93802 & 0.118248 & 2.383844 \\
20 & 1720.684 & 0.024938 & 0.004640 & 0.070488 & 0.020250 & 61.38697 & 35.98049 & 0.115927 & 2.396293 \\
\hline
\end{tabular}

The REER and interest rate variations (Tables 3 and 4) depend primarily on global factors rather than domestic macroeconomic variables. The variation in these variables can be explained by the global demand 
shock, inflation rate dynamics and oil prices. These three sources jointly explain 99 percent of the variation in the REER as well as interest rate in the short run. Given China's high degree of openness, these variables may also influence the economy in the longer run. The only exception is the domestic interest rate: domestic variables account for about 7 percent of the variation in the first quarter. The inability of the domestic central bank to control inflation and the interest rate is evident here and could probably be attributed to the economy's high degree of openness and large FDI inflows.

Table 3: FEVD analysis for REER

\begin{tabular}{lccccccccc}
\hline Period & SE & $\begin{array}{c}\text { Fiscal } \\
\text { policy } \\
\text { shock }\end{array}$ & $\begin{array}{c}\text { Cost } \\
\text { push } \\
\text { shock }\end{array}$ & $\begin{array}{c}\text { Risk } \\
\text { premium } \\
\text { shock }\end{array}$ & $\begin{array}{c}\text { Interest } \\
\text { rate } \\
\text { shock }\end{array}$ & $\begin{array}{c}\text { Global } \\
\text { demand } \\
\text { shock }\end{array}$ & $\begin{array}{c}\text { Global } \\
\text { cost } \\
\text { push } \\
\text { shock }\end{array}$ & $\begin{array}{c}\text { Global } \\
\text { interest } \\
\text { rate } \\
\text { shock }\end{array}$ & $\begin{array}{c}\text { Oil } \\
\text { price } \\
\text { shock }\end{array}$ \\
\hline 1 & 6.481647 & 0.002892 & 0.016133 & 0.010024 & 0.114417 & 55.48864 & 37.82077 & 0.201804 & 6.345325 \\
2 & 6.947161 & 0.082979 & 0.015105 & 0.008728 & 0.258944 & 55.98468 & 37.29965 & 0.186612 & 6.163299 \\
3 & 6.975591 & 0.164335 & 0.016096 & 0.008688 & 0.323463 & 55.97884 & 37.02822 & 0.295394 & 6.184963 \\
4 & 7.054316 & 0.259661 & 0.017646 & 0.011122 & 0.384990 & 55.42695 & 37.01853 & 0.404807 & 6.476295 \\
8 & 7.548679 & 0.279289 & 0.017203 & 0.028168 & 0.376604 & 55.78519 & 36.61905 & 0.406921 & 6.487577 \\
12 & 12.49115 & 0.259634 & 0.011538 & 0.071002 & 0.219180 & 57.12387 & 36.23716 & 0.372196 & 5.705420 \\
16 & 13.23550 & 0.259269 & 0.011558 & 0.069630 & 0.207843 & 56.77222 & 36.20050 & 0.378001 & 6.100982 \\
20 & 13.28324 & 0.267869 & 0.011533 & 0.070265 & 0.216298 & 56.78090 & 36.12884 & 0.382837 & 6.141455 \\
\hline
\end{tabular}

Table 4: FEVD analysis for interest rate

\begin{tabular}{lccccccccc}
\hline Period & SE & $\begin{array}{c}\text { Fiscal } \\
\text { policy } \\
\text { shock }\end{array}$ & $\begin{array}{c}\text { Cost } \\
\text { push } \\
\text { shock }\end{array}$ & $\begin{array}{c}\text { Risk } \\
\text { premium } \\
\text { shock }\end{array}$ & $\begin{array}{c}\text { Interest } \\
\text { rate } \\
\text { shock }\end{array}$ & $\begin{array}{c}\text { Global } \\
\text { demand } \\
\text { shock }\end{array}$ & $\begin{array}{c}\text { Global } \\
\text { cost } \\
\text { push } \\
\text { shock }\end{array}$ & $\begin{array}{c}\text { Global } \\
\text { interest } \\
\text { rate } \\
\text { shock }\end{array}$ & $\begin{array}{c}\text { Oil } \\
\text { price } \\
\text { shock }\end{array}$ \\
\hline 1 & 4.264646 & 3.157346 & 0.009424 & 0.540077 & 4.002030 & 62.11363 & 25.54066 & 0.205107 & 4.431732 \\
2 & 8.386646 & 1.202949 & 0.011249 & 0.250966 & 1.380082 & 60.02498 & 32.88594 & 0.352549 & 3.891282 \\
3 & 8.403721 & 1.252972 & 0.011267 & 0.267538 & 1.516278 & 59.80576 & 32.80828 & 0.357395 & 3.980514 \\
4 & 9.777168 & 0.930281 & 0.010232 & 0.214015 & 1.121081 & 58.89171 & 33.76622 & 0.333669 & 4.732787 \\
8 & 22.01669 & 0.213607 & 0.009757 & 0.081931 & 0.222118 & 56.04233 & 36.25793 & 0.338182 & 6.834138 \\
12 & 25.68963 & 0.185180 & 0.008551 & 0.093393 & 0.189077 & 58.03857 & 35.69487 & 0.275207 & 5.515159 \\
16 & 28.29561 & 0.168326 & 0.008620 & 0.090651 & 0.158024 & 58.76087 & 35.51909 & 0.238256 & 5.056167 \\
20 & 30.31351 & 0.152791 & 0.008275 & 0.089268 & 0.138328 & 59.44485 & 35.25642 & 0.210241 & 4.699826 \\
\hline
\end{tabular}

So far, the global inflation rate and increased global demand for goods and services, along with endogenous oil price variations, seem to play a major role in China's macroeconomic dynamics. These three variables account for almost 99 percent of the variation in each domestic variable in the short run as well as in the long run. The overall analysis confirms the ineffectiveness of domestic policy variables in influencing the major macroeconomic variables in a highly open economy.

Global demand shocks are the most important factor explaining the variation in oil prices (Table 5). Aggregate global demand shocks explain 55 
percent of the variance in the short run and 61 percent of the forecast error variance in the long run. This is followed by global cost-push shocks, which account for 29 percent of the variation in the second quarter and about 35 percent after five years. The world interest rate accounts for about 2 percent of the variation in the third and fourth quarters only. China's output gap explains only 1 percent of the forecast error variance in the short run.

Table 5: FEVD analysis for oil price

\begin{tabular}{lccccccccc}
\hline Period & SE & $\begin{array}{c}\text { Fiscal } \\
\text { policy } \\
\text { shock }\end{array}$ & $\begin{array}{c}\text { Cost } \\
\text { push } \\
\text { shock }\end{array}$ & $\begin{array}{c}\text { Risk } \\
\text { premium } \\
\text { shock }\end{array}$ & $\begin{array}{c}\text { Interest } \\
\text { rate } \\
\text { shock }\end{array}$ & $\begin{array}{c}\text { Global } \\
\text { demand } \\
\text { shock }\end{array}$ & $\begin{array}{c}\text { Global } \\
\text { cost } \\
\text { push } \\
\text { shock }\end{array}$ & $\begin{array}{c}\text { Global } \\
\text { interest } \\
\text { rate } \\
\text { shock }\end{array}$ & $\begin{array}{c}\text { Oil } \\
\text { price } \\
\text { shock }\end{array}$ \\
\hline 1 & 1.000405 & 0.000000 & 0.000000 & 0.000000 & 0.000000 & 0.080900 & 0.000000 & 0.000000 & 99.91910 \\
2 & 3.662825 & 0.832410 & 0.010517 & 0.000069 & 1.374353 & 55.41690 & 29.43203 & 0.150287 & 12.78343 \\
3 & 4.582119 & 0.993976 & 0.006930 & 0.039529 & 1.219980 & 53.85571 & 20.98860 & 2.008252 & 20.88702 \\
4 & 5.711451 & 0.728963 & 0.004625 & 0.077489 & 0.853351 & 57.69804 & 19.91328 & 1.806790 & 18.91747 \\
8 & 30.27477 & 0.084215 & 0.010483 & 0.035346 & 0.206535 & 61.31755 & 34.74978 & 0.249950 & 3.346141 \\
12 & 35.77726 & 0.080444 & 0.008718 & 0.048124 & 0.157701 & 61.45984 & 35.21522 & 0.238918 & 2.791033 \\
16 & 36.53691 & 0.111318 & 0.008495 & 0.052532 & 0.185759 & 61.63278 & 35.01896 & 0.260360 & 2.729796 \\
20 & 37.29742 & 0.108512 & 0.008412 & 0.051676 & 0.181951 & 61.48358 & 35.11068 & 0.256690 & 2.798492 \\
\hline
\end{tabular}

\section{Conclusion}

The study's key findings suggest that global economic conditions have a significant impact on China's economy. Domestic policy variables, including fiscal and monetary policy shocks, appear to have the least influence on the country's macroeconomic dynamics. Global demand shock is the most important variable, with positive implications for domestic GDP and other variables. Collectively, the global demand shock and global costpush shock (excluding oil price shocks) explain more than 90 percent of the variation in the Chinese economy for any horizon (up to five years in this study). In the case of positive oil price shocks, China's GDP experienced a downward trend that lasted a year and a half. The decline in inflation following an oil price hike can be explained by the substantial decrease in demand for Chinese products due to a slump in the rest of the world. The inflation rate in the rest of the world follows a positive trend due to the high marginal cost of production.

The study's most important finding is the FVED of the international oil price level. Our results confirm the oil price endogeneity hypothesis: oil price variations depend primarily on global economic conditions in the long run. Oil prices start responding to global economic conditions in the second quarter. Global demand shocks play a major role in shaping oil market dynamics and explain up to 61 percent of the variation in oil prices. However, the interest rate appears to cause no variation in oil prices in any horizon. 


\section{References}

Backus, D., \& Crucini, M. (2000). Oil prices and the terms of trade. Journal of International Economics, 50(1), 185-213.

Bernanke, B. S., Gertler, M., \& Watson, M. (1997). Systematic monetary policy and the effects of oil price shocks. Brookings Papers on Economic Activity, 28(1), 91-157.

Blanchard, O. J., \& Galí, J. (2009). The macroeconomic effects of oil price shocks: Why are the 2000s so different from the 1970s? In J. Galí \& M. Gertler (eds.), International dimensions of monetary policy (pp. 373428). Chicago: University of Chicago Press

Blanchard, O. J., \& Riggi, M. (2011). Why are the 2000s so different from the 1970s? A structural interpretation of changes in the macroeconomic effects of oil prices in the US (Working Paper No. 835). Rome: Banca d'Italia.

Calvo, G. A. (1983). Staggered prices in a utility-maximizing framework. Journal of Monetary Economics, 12(3), 383-398.

Campolmi, A. (2008). Oil price shocks: Demand vs supply in a two-country model (Working Paper No. 2008/5). Budapest: Magyar Nemzeti Bank.

Chen, K. C., Chen, S., \& Wu, L. (2009). Price causal relations between China and the world oil markets. Global Finance Journal, 20(2), 107-118.

Clarida, R., Galí, J., \& Gertler, M. (2002). A simple framework for international monetary policy analysis (Working Paper No. 8870). Cambridge, MA: National Bureau of Economic Research.

Cong, R.-G., Wei, Y.-M., Jiao, J.-L., \& Fan, Y. (2008). Relationships between oil price shocks and stock market: An empirical analysis from China. Energy Policy, 36(9), 3544-3553.

Du, L., He, Y., \& Wei, C. (2010). The relationship between oil price shocks and China's macro-economy: An empirical analysis. Energy Policy, 38(8), 4142-4151. 
Edelstein, P., \& Kilian, L. (2007). The response of business fixed investment to changes in energy prices: A test of some hypotheses about the transmission of energy price shocks. BE Journal of Macroeconomics, $7(1), 1-41$.

Edelstein, P., \& Kilian, L. (2009). How sensitive are consumer expenditures to retail energy prices? Journal of Monetary Economics, 56(6), 766-779.

Fan, G. (2008). China's economic growth in a context of globalization (Asie Visions No. 7). Paris: Institut Français des Relations Internationales.

Faria, J. R., Mollick, A. V., Albuquerque, P. H., \& León-Ledesma, M. A. (2009). The effect of oil price on China's exports. China Economic Review, 20(4), 793-805.

Ferderer, J. P. (1996). Oil price volatility and the macroeconomy. Journal of Macroeconomics, 18(1), 1-26.

Galí, J., \& Monacelli, T. (2005). Monetary policy and exchange rate volatility in a small open economy. Review of Economic Studies, 72, 707-734.

Hamilton, J. D. (1983). Oil and the macroeconomy since World War II. Journal of Political Economy, 91(2), 228-248.

Hamilton, J. D. (2009). Causes and consequences of the oil shock of 2007-08 (Working Paper No. 15002). Cambridge, MA: National Bureau of Economic Research.

Hansen, L. P., \& Hodrick, R. J. (1980). Forward exchange rates as optimal predictors of future spot rates: An econometric analysis. Journal of Political Economy, 88(5), 829-853.

Hooker, M. A. (1996). What happened to the oil price-macroeconomy relationship? Journal of Monetary Economics, 38(2), 195-213.

Hooker, M. A. (1999). Oil and the macroeconomy revisited (Finance and Economic Discussion Series No. 99-43). Washington, DC: Board of Governors of the Federal Reserve System.

Huang, Y., \& Guo, F. (2007). The role of oil price shocks on China's real exchange rate. China Economic Review, 18(4), 403-416. 
Keating, J. W. (1990). Identifying VAR models under rational expectations. Journal of Monetary Economics, 25(3), 453-476.

Keating, J. W. (2000). Macroeconomic modeling with asymmetric vector autoregressions. Journal of Macroeconomics, 22(1), 1-28.

Kilian, L. (2009). Not all oil price shocks are alike: Disentangling demand and supply shocks in the crude oil market. American Economic Review, 99(3), 1053-1069.

Mark, N. C., \& Wu, Y. (1998). Rethinking deviations from uncovered interest parity: The role of covariance risk and noise. Economic Journal, 108(451), 1686-1706.

Mork, K. A. (1989). Oil and the macroeconomy when prices go up and down: An extension of Hamilton's results. Journal of Political Economy, 97(3), 740-744.

Nawaz, S. N., \& Ahmed, A. M. (2015). New Keynesian macroeconomic model and monetary policy in Pakistan. Pakistan Development Review, 54(1), 55-71.

Ou, B., Zhang, X., \& Wang, S. (2012). How does China's macro-economy response to the world crude oil price shock: A structural dynamic factor model approach. Computers and Industrial Engineering, 63(3), 634-640.

Sun, P., \& Heshmati, A. (2010). International trade and its effects on economic growth in China (Discussion Paper No. 5151). Bonn: Institute for the Study of Labor.

Tang, W., Wu, L., \& Zhang, Z. (2010). Oil price shocks and their short- and long-term effects on the Chinese economy. Energy Economics, 32 (Suppl. 1), S3-S14.

United Nations Conference on Trade and Development. (2014, January 28). Global investment trends monitor (No. 15). Geneva: Author.

Wang, X., \& Zhang, C. (2014). The impacts of global oil price shocks on China's fundamental industries. Energy Policy, 68, 394-402.

Woodford, M. (2007). Globalization and monetary control (Working Paper No. 13329). Cambridge, MA: National Bureau of Economic Research. 
Wu, G., \& Zhang, Y.-J. (2014). Does China factor matter? An econometric analysis of international crude oil prices. Energy Policy, 72, 78-86.

Zhang, C., \& Chen, X. (2014). The impact of global oil price shocks on China's bulk commodity markets and fundamental industries. Energy Policy, 66, 32-41. 